\title{
Effect of nutrition on Crassostrea gigas larval development and the evolution of physiological indices. Part A: Quantitative and qualitative diet effects
}

\author{
R. Ben Kheder ${ }^{\mathrm{a}}$, C. Quéré ${ }^{\mathrm{a}}$, J. Moal ${ }^{\mathrm{a}}$ and R. Robert ${ }^{\mathrm{a},{ }^{*}}$
}

\author{
a Ifremer, Laboratoire de Physiologie des Invertébrés Marins, Station Expérimentale d'Argenton, Presqu'île du \\ Vivier, 29840 Landunvez, et Centre de Brest, BP 70, 29280 Plouzané, France \\ *: Corresponding author : R. Robert, Tel.: + 332988951 05; fax: + 332988957 77, email address : \\ rene.robert@ifremer.fr
}

\begin{abstract}
:
Several quality indices have been defined for marine bivalve larvae, including the coloration of whole larvae and the Triacylglycerols/Sterols ratio (TAG/ST), putting emphasis on the role of lipids in larval development. Using an image analysis system, epifluorescence microscopy and Nile Red, to specifically colour the reserves, we improved and quantified the overall physiological index based on the ratio of the lipid surface to the total larval surface. This Overall Lipid Index (OLI) was then tested in two experiments on the influence of nutritional parameters on larval development and metamorphosis in Crassostrea gigas, following the parallel evolution of the indices. The higher the input of microalgae, the quicker larvae developed, leading to a maximum development rate of $16.5 \mu \mathrm{m} \mathrm{d}^{-1}$. This rate was accompanied by the highest lipid reserves. At the end of rearing, the lipid reserves occupied $30 \%$ of the larval surface in the batches with the highest food ration, while they only covered $12 \%$ in the larvae on the lowest ration. In the same way, the TAG/ST ratio increased over the rearing period and reached its highest levels in larvae with the highest food ration. We also noted that the decrease in lipids over the first week of rearing was higher when the nutritional input was lower. Finally, deficient reserves and poor performances were recorded in larvae fed only the flagellates Pavlova lutheri $(\mathrm{P})$, Isochrysis affinis galbana $(\mathrm{T})$ or a mixture of these species (PT). In contrast, a high lipid accumulation and better performances were shown when the diet was based on the diatom C. calcitrans f. pumilum (Cp), whether alone or in combination with other species.
\end{abstract}

Keywords: Crassostrea gigas; Larvae; Growth; Metamorphosis; Nutrition level and quality; Lipids; Condition indices 


\section{Introduction}

Due to the decimation of Crassostrea angulata stocks by an epizootic, several hundred tonnes of Crassostrea gigas were imported from 1971 to 1973 to serve as new broodstock in sanctuaries in France. The species, imported from British Columbia (Canada), became established, and abundant spat settlement in Marennes-Oleron allowed healthy, fast-growing oysters to be produced (Grizel and Héral, 1991). Meanwhile, another 10000 t spat were imported from Japan, and production increased quickly. Spat capture developed rapidly in Arcachon and Marennes-Oleron, so that further spat imports became unnecessary (Buestel et al., 2008) and French C. gigas production relied progressively on local stocks.

Nowadays French oyster production relies on spat that are principally collected in the wild, with three-quarters of these juveniles supplied from the nursery basins of Marennes-Oléron and Arcachon (AGRESTE, 2005). Up until the last decade, the supply of hatchery spat was relatively small and served to complement natural supplies when capture from the wild was insufficient (Robert and Gérard 1999). However, the inter-annual variation in capture noted since 1998 in the main French nursery area (Auby and Maurer, 2004; Pouvreau et al., 2008) and the growing demand for new shellfish farming products like triploids (Normand et al., 2009) have gradually increased this hatchery production from 5 to $25 \%$. Because the larval stages are presently thought to be the most critical stages in the life of bivalves and despite a high level of technical know-how in commercial hatcheries today, many biological questions on these stages remain unanswered. This means that, as yet, there are no reliable tools for predicting the health of a larval rearing batch.

There are presently no suitable condition indices for bivalve larvae that allow quality and success of larval growth and/or metamorphosis to be predicted. The practical usefulness of such indices is undeniable: they can reveal possible perturbations before they are shown by a halt in growth and/or death of individuals. Among the approaches that have been explored, the importance of lipids in larval rearing performance of molluscs is particularly well supported in the literature. It has been shown that diets rich in lipids are especially beneficial for larval growth in C. gigas (Powell et al., 2002), Argopecten purpuratus (Nevejean et al., 2003) and Pecten maximus (Delaunay et al., 1993; Tremblay et al., 2007). A lipid-rich diet also increases competence to metamorphosis in $C$. gigas (which has higher needs in terms of lipids than C. virginica (Haws and DiMichele, 1993)) as well as in P. maximus (Tremblay et al., 2007). It is therefore not surprising that previous studies have sought to use such lipid approaches. Thus, Gallager and Mann $(1981,1986)$ and Gallager et al., (1986) provided a visual index for estimating lipid resources in bivalve larvae on a relative basis using the lipid specific stain, Oil Red O. However, as results were highly heterogeneous, only a broad trend was obtained.

Such index seemed to be particularly well correlated with survival, as high survival rates were found to be linked to high levels of lipids, although the opposite was not true (univocal relationship: Gallager et al., 1986). In addition, these authors suggested using lipids as a predictive indicator for metamorphosis in the two bivalve species $C$. virginica and Mercenaria mercenaria. Previous work on overall lipid indices have mostly been based on a semiquantitative scale and the results were highly heterogeneous, partly due to the limitations posed by rearing conditions (e.g. monospecific diet). These indices only allowed strong trends to be revealed: indices of 0 and 1 were linked to metamorphosis percentages below $10 \%$ and indices of 2 and 3 to percentages between 10 and $90 \%$. Image analysis of photographs offers possibilities of improving overall lipid index and it was the primary objective of the present study to apply such a method to this objective.

Another index, triacylglycerols/sterols (TAG/ST), has already been used to estimate larval quality in Placopecten magellanicus (Pernet et al., 2003). Tricylglycerols are known to be the principal constituent of reserves in larvae of C. gigas (Whyte et al., 1987; Waldock and Nascimento, 1979), and P. maximus (Delaunay et al., 1993). Sterols, on the other hand, while classed as neutral lipids according to their polarity, are integrated into structural membranes to give rigidity. They increase with the membrane surface as these increase in 
size, and can therefore represent a reference weighted according to lipid reserves. In $P$. magellanicus, a relation was revealed between TAG/ST and level of metamorphosis competence (Pernet et al., 2003).

Finally, the ratio of organic matter to dry matter (OM/DW), considered by many authors to be a relevant physiological indicator, was also examined in the present work. Both organic matter and dry weight have been seen to increase at the end of the pelagic stage in $C$. gigas (His and Maurer, 1988). According to these authors, this organic matter accumulation corresponds to the critical metamorphosis period. The same pattern has been seen in the blue mussel Mytilus edulis (Lucas et al., 1986) and the scallop Patinopecten yessoensis (Whyte et al., 1987). The relative percentage of organic matter (100* OM / DW) was considered by these last authors to be a good indicator of larval metamorphosis competence, but this same index (called Larval Condition Index) showed a weak correlation with the rate of metamorphosis in P. maximus (Robert et al., 1999). In the present study, we sought to test its validity as a predictor of metamorphosis in the Pacific oyster, where metamorphosis is much more rapid (2-7 d compared with 7-14 $\mathrm{d}$ in the scallop $P$. maximus).

The objective of this work was therefore to study the evolution and relevance of these three indices throughout the pelagic cycle in $C$. gigas larvae subjected to different nutritional conditions in a controlled environment. The first part of this study (A), described in the present paper, addresses the effects of quantity and quality of food, while a second paper (B) concerns the effects of temporary food deprivation. In the present work two experiments are reported, the first on the influence of the food ration and the second on the impact of the quality of algal diet (species composition) on survival, growth, metamorphosis and development of lipid reserves measured by these different indices.

\section{Materials and methods}

\subsection{Broodstock conditioning, microalgal culture, larval development and competence}

Genitors aged 2 years, issued from the same batch of origin (spatfall from Arcachon) were stocked at Aber Benoît (North Brittany) with regular transfers to the Argenton experimental station for conditioning. Sixty individuals were placed in $800 \mathrm{I}$ tanks for 1.5 months in flow through at $19{ }^{\circ} \mathrm{C}$ with a daily phytoplankton supply equivalent to $6 \%$ of oyster dry weight.

Three microalgae species were supplied in equal quantity in an equivalent volume: Isochrysis affinis galbana (T. Iso = T, strain CCAP 927/14), Chaetoceros gracilis (Cg, strain Utex LB 2375) and Skeletonema marinoi (S, strain CCAP 1077/3). Microalgae were initially cultured in 250-ml Erlenmeyer flasks and then in 2-I, 6-I, 10-I glass carboys and finally in 300I Perspex cylinders, in batch cultures. Large scale cultures (300-I) were generally devoted to broodstock conditioning while 6 to 10-I cultures were used for larvae. Seawater at ambient salinity (33-34 ppt) was 1- $\mu \mathrm{m}$ filtered, enriched with sterilised Conway medium (Walne, 1966) and either autoclaved $(\leq 10-I)$ or U.V. treated. For diatoms culture sodium metasilicate (40 $\mathrm{mg}^{-1}$ ) was added as a silica source and salinity was reduced to $25 \mathrm{ppt}$ by addition of distilled water. Temperature and continuous illumination, provided by white fluorescent tubes, ranged between $19-20^{\circ} \mathrm{C}$ and $35-50 \mu \mathrm{mol}$ photons $\mathrm{m}^{-2} \mathrm{~s}$ (flasks) and $22-23^{\circ} \mathrm{C}$ and $180-220 \mu \mathrm{mol}$ photons $\mathrm{m}^{-2} \mathrm{~s}$ (carboys and cylinders) respectively. Carboys and cylinders were aerated with a $3 \% \mathrm{CO}_{2}$ /air mixture to support growth and to maintain the $\mathrm{pH}$ within a range of 7.5-8.1. To be used as diets, microalgae were harvested at the end of the exponential phase.

So as to minimise genetic effects, the gametes of three males and six females were separately mixed after stripping the gonads of the genitors. After counting, fertilisation was performed at a ratio of 50 spermatozoids per oocyte. Two hours later, the embryos were put to incubate in 150 I cylindro-conical tanks at a density of 40 embryos $\mathrm{ml}^{-1}$. Seawater filtered 
at $1 \mu \mathrm{m}$ was regulated at $24 \pm 1{ }^{\circ} \mathrm{C}$ and mixed by air bubbling from the base of the cone $(0.5 \mathrm{I}$ $\left.\mathrm{min}^{-1}\right)$. At the end of $48 \mathrm{~h}$ incubation, the percentage of D-larvae was determined and the veligers transferred to cylindro-conical tanks of 30 or 150 I depending on the experiment.

Towards the end of the pelagic cycle (16-19 d) the larvae, which by now had a foot, developed a pigmented spot known as an eye (Coon et al., 1990; Baker and Mann, 1994). These larvae, considered as ready to metamorphose or 'competent' were counted and the percentage of competence determined. Selective sieving was made on a sieve of $225 \mu \mathrm{m}$ mesh size. The selected larvae were returned to water at a density of 2 pediveligers $\mathrm{ml}^{-1}$, in 30 I tanks in which plastic discs for settlement of $15 \mathrm{~cm}$ diameter had been placed. The rearing conditions were similar to those maintained during larval development. After 5 days, the percentage of metamorphosis was calculated indirectly by estimating the number of free non-settled larvae (swimming and dead).

\subsection{Experimental trials}

The influence of quantity and quality of food on larval rearing performances and the building of lipid reserves was tested in two independent experiments.

In the first experiment, the influence of food quantity was estimated by feeding larvae at three levels, in triplicate: half ration (25-100 cells $\left.\mu^{-1}\right)$, standard ration (50-200 cells $\mu^{-1}$ : RicoVilla et al., 2006) and double ration (100-400 cells $\left.\mu^{-1}\right)$, of a bi-specific mixture of $I$. affinis galbana (T) and Chaetoceros calcitrans forma pumilum (CCAP 1010/05 (Cp)) fed 50/50 in equivalent volume. The experiment was conducted in three 150-I and three 450-I cylindro-conical tanks. The 150-I tanks served as control references for monitoring larval development (growth and survival), because the larval density remained constant throughout the rearing period. The 450-I tanks were used for the biological samples (physiological indices), which required a greater number of larvae; these tanks were also used for the measurements to determine competence and percentage metamorphosis. The effect of tank volume (150 I vs. 450 I) had previously been tested and no significant effect on larval performances detected (Nicolas, 1999).

The second experiment tested the influence of each species of microalga, and paired combinations at equal volume. The larvae were reared in triplicate in 30-I tanks and fed daily according to their needs, estimated by particle counts (grazing), on monospecific diets composed of Pavlova lutheri: CCAP 931/1 (P), I. affinis galbana (T), C. calcitrans forma pumilum (Cp) or on bi-specific mixtures (PT, PCp, TCp) mixed in equal proportions, with equal volume. Microalgae used for larvae exhibited similar cell size in their exponential phase of growth (40 to $45 \mu \mathrm{m}^{3}$ ) equivalent to 4.2 to $4.4 \mu \mathrm{m}$ diameter) as well as similar dry individual weight (18 to 20pg: Robert et al., 2004) and mixed feeding ration was accordingly based on a ration 1:1. The rations varied from 15 to 180 cells $\mu^{-1}$ across all the diets and ages. Positive control consisted in trispecific diet PTCp.

All rearing was conducted sequentially with seawater renewed every two days and a larval density of 5 larvae $\mathrm{ml}^{-1}$. Seawater, filtered to $1 \mu \mathrm{m}$, was maintained at $24 \pm 1^{\circ} \mathrm{C}$ at ambient salinity (34 ppt) with no added antibiotics. Algae were distributed once a day. Light air bubbling from the bottom of the cone was applied throughout the rearing period to mix the larvae and algae in the water column and avoid an accumulation of organic matter that could encourage bacterial development.

Over the larval rearing period and at each water renewal, the larvae were recovered by draining the tanks. They were counted to estimate survival and then 200 to 300 larvae were sampled and stored in 3-ml wells of 24-cell microcellular plates filled with 1- $\mu \mathrm{m}$ filtered seawater and fixed with a 5\% formalin solution. For each well, the entire population was photographed using Win Imager software under an inverted microscope (Olympus, type IMT2), avoiding photographic overlap. The photographs were then treated by image analysis using the software Imaq Vision Builder version 6.0 allowing the surface of each object to be 
determined and its length calculated (de Pontual et al., 1998) and larval growth accordingly achieved.

\subsection{Quantification of reserve lipids and definition of overall lipid index}

The lipid reserves of $C$. gigas larvae were revealed according to the protocol of Castell and Mann (1994). A stock solution of Nile Red was prepared by adding acetone as a solvent vector $\left(250 \mathrm{\mu g} \mathrm{ml}^{-1}\right)$. The larvae were first starved for at least six hours to reduce interference from undigested algal lipids. They were then transferred to Eppendorf tubes containing $2 \mathrm{ml}$ filtered seawater, to which $10 \mu \mathrm{l}$ of Nile Red solution were then added.

After a 90 min contact time, the larvae were rinsed in filtered seawater and fixed in formaldehyde. Microscopic examination was made under an epifluorescence microscope (Laborlux Leica), equipped with a HBO 50 WIAC mercury vapour lamp and I3 filter block for PLOEMOPAK illuminator (band-pass excitation filter providing transmission at 450-490 nm). A Leica NPL 10/0.25 objective was used. The photographs were taken with a colour camera (Leica DFC320), resistant to the heating that occurs with epifluorescence, within four hours of coloration so as to avoid any deterioration of the fluorescence.

The photographs were then treated by image analysis using Imaq Vision Builder version 6 . Following conversion, using a previously-established script, the colours represented by greyscale corresponded to the lipid surface revealed by Nile Red and the total surface of the larva (Fig. 1), the ratio of the surface of the image occupied by the lipids to the total surface of the larva was determined. This analysis was made on 50 individuals per tank.

\subsection{Structual biochemical index (triacylglycerols / sterols: TAG/ST)}

A sample of larvae, varying from 50000 to 200000 according to their development stage, were taken on each second day. The larvae were collected on a (previously precombusted) GF/C filter and put in $6 \mathrm{ml}$ tubes of Folch's liquid (2:1 chloroform:methanol) in which they were stored at $-20{ }^{\circ} \mathrm{C}$ until use. Just before the analysis, all the samples were ground by sonification and centrifuged for $10 \mathrm{~min}$ at $100 \mathrm{rpm}$. Neutral lipid classes were analysed by HPTLC (high performance thin layer chromatography) using a CAMAG system, consisting of a sampler (TLC Sampler 4) and a reader (TLC Scanner 3). Silica plates (HPTLC plates silica gel $60,10 * 20 \mathrm{~cm}$, Merck) previously cleaned with a 1:1 hexane-diethyl ether mixture, were activated for 30 minutes at $120{ }^{\circ} \mathrm{C}$. The lipid samples $(\approx 3 \mu \mathrm{g})$ were put through a double migration: first with a hexane-diethyl ether-acetic acid mixture (20:5:0.5), then with a hexanediethyl ether mixture (97:3). The lipid classes appeared as black marks after the silica plates had been soaked in a solution of copper sulphate (3\%)-orthophosphoric acid (8\%) and heated to $120{ }^{\circ} \mathrm{C}$ for 20 minutes. To quantify the lipid classes, a mixture of standards was deposited on each plate. This mixture of standards was prepared in similar proportions to those found in the neutral lipids of oysters: $58 \%$ menhaden oil for the triglycerides, $14 \%$ cholesterol for the sterols, $3 \%$ 1-octadecanol for the alcohols, $10 \%$ cholesterol palmitate for the sterol esters, $13 \%$ 1-0 hexadecyl-2,3 dipalmitoyl-rac-glycerol for the glyceride ethers and $2 \%$ stearic acid for the free fatty acids. Results were obtained by making readings at $370 \mathrm{~nm}$ and quantifying the marks with the Wincats program; the sterols and triglycerides were expressed in $\mu g$ per larva.

\subsection{Larval condition index: relative organic matter content (OM/DW)}


Depending on the larval stage, samples of $n=10000$ to 1000000 larvae, made in duplicate, were concentrated on a $40 \mu \mathrm{m}$ sieve and rinsed with an aqueous isotonic solution of ammonium formate $\left(32 \mathrm{~g} \mathrm{l}^{-1}\right)$. After transfer into hemolysis tubes, the samples were preserved at $-20^{\circ} \mathrm{C}$ until use. The larvae were then transferred into an aluminium cap that had previously been weighed and burnt. Dry weight was obtained after $48 \mathrm{~h}$ in a drying oven at $65^{\circ} \mathrm{C}$, and organic weight obtained by the difference in weight after $4 \mathrm{~h}$ in a muffle furnace at $460{ }^{\circ} \mathrm{C}$. The weights were measured to a precision of $10 \mu \mathrm{g}$ on a microbalance (Sartorius, type CP225 D; $0.01 \mathrm{mg}$ to $1 \mathrm{~g}$ ).

\subsection{Statistics}

In most cases data were analysed by one-way analysis of variance followed by Fisher's Least Significant Difference pairwise comparison $(P<0.05)$; where necessary data were arcsine transformed to achieve homogeneity of variance and normality. Analyses were performed using Statview 5, SAS Software. Data are summarized as mean \pm standard deviation of the mean.

\section{Results}

\subsection{Effect of food ration}

\subsubsection{Larval performances}

The quantity of food supplied had a notable influence on the duration of the larval phase (Table 1). The higher the concentration of phytoplankton, the faster larval development took place and the shorter the pelagic phase overall. During the first week of rearing, no significant difference in growth was seen (Fig. 2): larvae measuring $78 \mu \mathrm{m}$ on day 2 reached a size of $132-138 \mu \mathrm{m}$ by day 7 , considering all diets together. Beyond this point in time, size differences became more marked between diets and growth rates statistically different. By day 14, the larvae on the lowest food ration measured only $192 \mu \mathrm{m}$ mean length, compared with $281 \mu \mathrm{m}$ for the larvae fed on the highest ration. The larvae fed the standard ration measured $303 \mu \mathrm{m}$ in mean length on day 18. Those given the double ration measured 309 $\mu \mathrm{m}$ on day 16, but those on the half ration measured only $283 \mu \mathrm{m}$ on day 25 (Fig. 2).

The double ration allowed a high percentage of larvae to reach competence (86\%) after 16 days (Table 1). On the half ration, larval competence was only reached nine days later and by only about one third the number of larvae. Metamorphosis success was only $50 \%$ in the half ration treatment whereas it reached $\approx 80 \%$ with the standard ration and double ration, which were not significantly different from one another $(p=0.1609$, Table 1$)$. Survival was high for all three batches (> $86 \%)$.

\subsubsection{Overall lipid index}

Results reveal a positive relationship between the quantity of food received and the levels of reserves accumulated (Fig. 3). In a 2-day-old larva, lipids covered about $30 \%$ of the surface. Then, regardless of the phytoplankton input level, these reserves were catabolised until day 8. This effect was very strong in the underfed (half ration) larvae, where the lipid surface was only $1.3 \%$ on day 8 compared with 13 and $19 \%$ for the reference and double ration diets, 
respectively. The larvae subsequently built up some reserves whatever the food ration (10 $\%, 20-30 \%$ : Fig. 3) in proportion to the level at which they were fed.

\subsubsection{Index of larval condition (OM/DW)}

Larval dry weight increased progressively over the first week, the levels moving from around $100 \mathrm{ng} \mathrm{larva}^{-1}$ at day 2 to $740-970 \mathrm{ng}$ larva $^{-1}$ at day 7 (all diets considered together), without showing any significant differences between the three rations ( $p>0.05$ : Fig. $4 a)$. From day 9 , the effect of dietary ration became more marked, but the difference between treatments did not really develop until day 14 . At this point, the low microalgal input led to larvae with a mean dry weight of $2100 \pm 64 \mathrm{ng} \mathrm{larva}^{-1}$ while a double ration led to a dry weight more than twice as large $\left(4899 \pm 332 \mathrm{ng}\right.$ larva $\left.^{-1}\right)$. At the end of the planktonic phase, a larva fed at the highest rate weighed $7630 \pm 820$ on average compared with $4667 \pm 45 \mathrm{ng}^{\text {larva }}{ }^{-1}$ at the lowest food level. Dry weight always followed an exponential pattern with time, whatever the food level $\left(D W=a e^{b t}\right)$, with increasing speeds $(b)$ in the order: half ration < standard ration < double ration. At the highest food level, the larvae showed weight increases twice as rapid as those of the underfed larvae.

The same pattern was seen for organic matter, where the evolution over time showed differences from the second week according to food ration (Fig. 4b). The weight of organic matter went from $32 \mathrm{ng}$ in a 2-day-old larva to $218 \pm 64 \mathrm{ng} \mathrm{larva}^{-1}$ and $562 \pm 3 \mathrm{ng}$ larva ${ }^{-1}$ on day 14 in the larvae fed on the lowest and highest rations, respectively. At the end of larval rearing, a low microalgal input was associated with a very low organic matter level (431 \pm 49 ng larva ${ }^{-1}$ ), while larvae fed the high ration had a value three times as large (1202 $\pm 359 \mathrm{ng}$ $\left.\operatorname{larva}^{-1}\right)$. The slope of the equation modelling the increase in organic matter, therefore, showed that this increased about twice as fast in highly fed individuals (Fig. 4b).

In 2-day-old D-larvae the OM/DW ratio was $32 \%$ (Fig. 5). By day 7, the larvae on the standard ration showed a slight decrease in this ratio (to $25 \%$ ), but it then remained stable until day $11(26 \%)$. Another decrease was then observed, to reach $9 \%$ on day 14 . At the end of larval rearing, on day 18, the ratio was $11 \%$. The same pattern was seen in larvae on the half ration, with no significant differences at any point in the experiment $(p>0.05)$. The only difference revealed between treatments in the experiment was at day 7 , when the larvae on double ration experienced a notable increase over the other two treatments to reach a value of $40 \%$.

\subsubsection{Structural biochemical index: TAG/ST}

From the first week, the accumulation of triacylglycerols and sterols in the larvae was strongly dependant on the quantity of food supplied (Figs. 6a and 6b). In larvae on the lowest ration, triacylglycerol levels remained low and increased from $1.8 \pm 0.1 \mathrm{ng}^{\text {larva }}{ }^{-1}$ on day 2 to only $27 \pm 8 \mathrm{ng}^{-1 a r v a}{ }^{-1}$ at the end of larval rearing (day 25) compared with increases to $214 \pm$ $32 \mathrm{ng} \mathrm{larva}^{-1}$ (day 18) and $237 \pm 71$ ng.larva $^{-1}$ (day 16), in medium and high rations, respectively. The accumulation of triacylglycerols by a larva follows an exponential relationship with time and the rates of increase were increasingly greater in the order: half ration < standard ration < double ration. The accumulation of triacylglycerols was, therefore, 2.5 times faster in larvae receiving twice the standard ration compared with those receiving half the standard ration.

The same pattern appeared for the sterols, although there was a less marked nutritional influence. The values in larvae on the half ration increased from $0.4 \pm 0.0 \mathrm{ng} \mathrm{larva}^{-1}$ on day 2 to $14.2 \pm 0.7 \mathrm{ng} \mathrm{larva}^{-1}$ at the end of larval rearing, compared with $26.5 \pm 3.9$ in larvae on the standard ration and $29.4 \pm 1.4 \mathrm{ng}^{\text {larva }}{ }^{-1}$ on the double ration (Fig. $6 \mathrm{~b}$ ). The accumulation of sterols by larvae over the course of their development followed an exponential law, with 
increasing speeds according to increasing ration once again - as in the triacylglycerols mentioned above (Fig. 6b).

A positive relationship was shown between ration level and the TAG/ST structural biochemical index (Fig. 7). With the lowest phytoplankton input, following an initial fall from 5 to 2 from the 2 nd to the 7 th day, values remained low and stable $(\approx 2)$ for the rest of larval development. Relatively stable values (5-6) were associated with the standard ration until day 11 . They then dropped by day 14 (3) and increased once more (7) just before metamorphosis (Fig. 7). Finally, the double food ration was associated with higher values: the ratio varied little until day 11 (7-9), diminished by day 14 (6) and rose once more at the end of larval development (9).

\subsection{Effect of food quality}

\subsubsection{Larval performances}

For all the larval rearing batches raised on monospecific diets, only the $\mathrm{Cp}$ diet gave good larval performances (Fig 8, Table 2). With a growth rate of $13.6 \mu \mathrm{m} \mathrm{d}^{-1}, 80 \%$ of the larvae were competent at day 18 , and $82 \%$ postlarvae recorded at day 25 . Apart from a lower survival $(75 \%)$, these performances were similar to those of the control fed on a mixture of 3 species PTCp. Diets T and P gave poorer results, with 9 and $6 \mu \mathrm{m} \mathrm{d}^{-1}$, respectively, and the larvae never reached competence, despite good survival throughout larval rearing (70 to 80 $\%)$. The same result was found with the mixture PT, which gave good growth $\left(11.5 \mu \mathrm{m} \mathrm{d}^{-1}\right)$ and survival (87 \%) to the end of larval rearing, nonetheless. On diet PCp, $28 \%$ of larvae were competent to metamorphose on day 18, giving $57 \%$ postlarvae. Finally, the best combination was TCp, with a growth rate of $15 \mu \mathrm{m} \mathrm{d}^{-1}, 86 \%$ of larvae competent by day 18 and $83 \%$ postlarvae obtained (Fig. 8, Table 2).

At day 14, the larval lengths were between 142 and $244 \mu \mathrm{m}$ and in three significantly different groups: $\mathrm{P}, \mathrm{T}$ and the group containing $\mathrm{Cp}$, alone and in mixtures (Fig. 8). These differences between and within groups widened at day 18 and the larvae fed TCp were significantly larger than in the other treatments $(320 \pm 30 \mu \mathrm{m} ; \mathrm{p}<0.0001)$. In decreasing order, the different treatments can be classed as follows: TCp> Cp $(299 \pm 32 \mu \mathrm{m})=$ PTCp $(293 \pm 43 \mu \mathrm{m})>$ PCp $(276 \pm 46 \mu \mathrm{m})>$ PT $(263 \pm 44)>\mathrm{T}(223 \pm 56 \mu \mathrm{m})>\mathrm{P}(175 \pm 47 \mu \mathrm{m})$.

\subsubsection{Overall lipid index}

On day 2, lipid reserves represented $30 \%$ of the larval surface (Fig. 9). When larvae received monospecific diets of $P$. Iutheri $(P)$ or $I$. affinis galbana $(T)$ OLI decreased to $4 \%$ on day 8 . This ratio dropped to $0.3 \%$ on day 15 for larvae fed $P$. lutheri but lipid reserves represented $17 \%$ of the larval surface when larvae were fed $I$. affinis galbana. The larvae in treatments PCp and TCp showed stabilisation of this ratio during the first week of rearing (at $30 \%$ ) and a decrease over the second week (to 14 and $18 \%$, respectively). For the diets PT and PTCp, a more progressive OLI decrease was noted over time: a first decrease was seen during the first week (19 and $20 \%$ respectively) and a second, more marked decrease was seen in the larvae fed the PT diet in the second week (5\%). In contrast, the rate of deposition of lipids was particularly high when larvae were fed C. calcitrans forma pumilum (Cp) with lipid reserves representing $33 \%$ of the larval surface on day 8 and $28 \%$ on day 15. 


\section{Discussion}

Throughout this study we analysed the relevance of indices describing the quality of larval rearing in $C$. gigas. Two of these indices aim to quantify the accumulation of neutral lipids in the larva. TAG (triacylglycerides) constitute the principal energetic reserves of oyster larvae (Whyte et al., 1987) and are preferentially catabolised in periods of starvation (Gallager et al., 1986). TAG content is also positively correlated with growth rate in C. gigas larvae (Waldock and Nascimento, 1979), P. maximus (Delaunay et al., 1992) and P. magellanicus (Pernet et al., 2006).

Nile Red is an excellent specific colorant for lipids (Greenspan and Fowler, 1985). Neutral and polar lipids are differentially coloured allowing energetic reserves (triacylglycerols and cholesteryl esters) to be easily identified and sterols to be coloured yellow in contrast to phospholipids, which emit a weak red-orange fluorescence (Greenspan et al., 1985; Brown et al., 1992; Castell and Mann, 1994). In the present study the evaluation of lipid reserves in C. gigas was performed in toto, according to the protocol of Castell and Mann (1994), initially developed for larvae of $C$. virginica, and also applied to larvae of $P$. magellanicus (Jackson, 1993). Using image analysis, the fluorescent surface and total surface of the larvae could be measured and quantified. The overall lipid index (OLI) is represented by the ratio between these two surfaces. OLI takes into account the variations in size and allowed the development of lipid reserves and their management over time to be followed throughout this work. The effect of the phytoplankton ration on the laying down of reserves in veligers was therefore clearly demonstrated, the overall lipid index being partially or totally correlated with larval development performances. Underfed larvae showed low levels of lipid reserves (OLI = 1 to $10 \%)$ accompanied by lower growth, competence and metamorphosis $\left(9 \mu \mathrm{m} . \mathrm{d}^{-1}, 32 \%\right.$ and $50 \%$, respectively). Inversely, larvae that received the highest ration had characteristically high lipid reserves (OLI $=15$ to $30 \%$ ), which coincided with the best performances (growth of $16.5 \mu \mathrm{m} \cdot \mathrm{d}^{-1}$ and $80 \%$ metamorphosis). The same patterns were seen in response to the food quality of different microalgae or their mixtures. A diet based solely on $P$. lutheri led to particularly poor lipid reserves (OLI $=0.3$ to $4 \%$ ) accompanied by low larval performance (6 $\mathrm{m} \mathrm{d}^{-1}$ and no metamorphosis), while feeding with mixtures including the diatom $C$. calcitrans forma pumilum led to high lipid reserve levels and good larval development $\left(>12 \mu \mathrm{m} \mathrm{d}^{-1}\right.$, metamorphosis $\left.>55 \%\right)$. However, this relationship between $\mathrm{OLI}$ and zootechnical performances is not absolute as, for example, the standard ration generated less lipid reserves than the double ration but had the same levels of larval survival and metamorphosis. As this index is based on the surface ratio, it does not take into account the intensity of coloration and, therefore, the concentration of the lipids. This explains why it is so highly influenced by larval size, as it probably represents the growth of the digestive gland, a storage organ for lipids in larvae. In contrast to classic biochemical analyses, the technique is simple, quickly performed and uses little biological material. However, this OLI has limitations in terms of application because it requires special equipment (epifluorescence) and fine and reproducible microscope regulation (filters, magnification, light, etc.). A detailed adjustment of the colour camera parameters (gain, exposure, colour saturation, etc.) must also be set up beforehand to obtain uniform image acquisition within an experimental series. It should also be noted that though we optimised the yellow fluorescence, and therefore the neutral lipid measurement, with the $<500 \mathrm{~nm}$ excitation filter, we did not filter the emission colour, and the values of total fluorescence could be influenced by background noise from phospholipids giving weak red emissions. In the same way, the position of the larva with respect to the image plane is also a source of variation in the measurement of surfaces, and three-dimensional microscopy (confocal) of the larval surface could, therefore, represent an interesting alternative. This method, allowing the viewing of the whole animal by sweeps of a laser, could offer a better estimation of lipid reserves than a conventional microscope where only a single cutting plane of an object is analysed. A new 
overall lipid index could then be developed, as the ratio between the volume of the image occupied by the lipids over the total volume of the individual.

The second index used to represent the concentration of neutral lipids in the larva was the TAG/ST ratio. Because sterols are structural lipids that vary little in the overall mass, they were chosen as a reference to compare larvae of different size. Their concentration in the membrane structure varies little except with temperature, enabling fluidity to be maintained (Roq et al., 2009). Sterols were favoured over phospholipids as the latter are more sensitive to the nutritional factor due to their energetic role in early larval stages and periods of starvation (Fraser, 1989; Delaunay et al., 1992), making the use of the TAG/PL ratio less appropriate for the estimation of larval quality. Our results demonstrated that the TAG/sterol ratio of $C$. gigas larvae was highly quantitatively dependant on the food ration. This index thus varied from 2 to 5 over larval development in larvae on the lowest ration and from 6 to 9 in larvae on the highest ration. These results agree with those of Farias et al. (2003) who described this ratio as sensitive to variation in food availability and as giving information on nutritional status of individuals rather than their physiological status. This correlation should be strong, as Hakanson (1989) showed that a ratio below 0.2 indicates a severe food deficiency in anchovy larvae Engraulis mordax, which causes severe irreversible effects. No such limit was recorded in the present study on the larvae of $C$. gigas, because, even for the underfed larvae, the lowest values of this ratio remained above this threshold and the larvae were able to survive, develop and metamorphose, though to a lesser extent than the betterfed treatments. Additionally, according to Pernet et al. (2003), a positive relationship was revealed between TAG/ST ratio measured on the $8^{\text {th }}$ day after fertilisation and the percentage of competence achieved (number of larvae ready for metamorphosis). Paradoxically, according to the same authors, this ration was negatively correlated with metamorphosis success, suggesting that larvae in good physiological condition spend more time searching for a suitable substrate for settlement, in contrast to larvae in poorer condition, which settle as soon as they have found a substrate. In the present study a decrease in the TAG/sterols ratio was noted on the 14th day, whatever the food ration supplied. For the standard and double ration diets, this decrease at the end of larval rearing could be explained by the mobilisation of reserves leading to a decrease or even a halt in ingestion for the metamorphosis process (Rico-Villa et al. 2009). This pattern did not occur at the lowest food ration, where competent larvae only appeared 10 days later.

The effect of food ration can also be seen to affect these two lipid indices from day 7-8, which is compatible with short phases of endotrophy and mixotrophy. C. gigas larvae are therefore capable of ingesting algae as early as the D-stage, this is to say $24 \mathrm{~h}$ after fertilisation (Lucas and Rangel 1983), while the mixotrophic phase lasts 4-5 days at rearing temperatures between 22 and $30^{\circ} \mathrm{C}$ (Rico-Villa et al., 2009). It is also interesting to note that at the end of rearing, the effect of algal ration on the settlement percentage became weak or

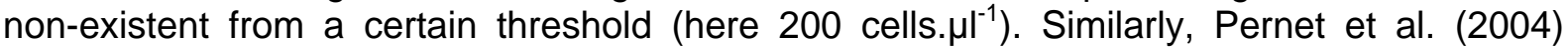
demonstrated that when Isochrysis and lipid microspheres impregnated with triacylglycerols were given to Mytilus edulis larvae just before metamorphosis, this led to an increase in larval triacylglycerol content that depended on the initial proportion of this compound in the food, but which provided no additional benefit for settlement.

Finally, our results show that the third index, OM/DW, was inadequate for representing the observed differences in performance. Despite an accumulation of dry and organic matter that was twice as fast in the highly-fed larvae compared with the underfed ones, the values of OM/DW ratio were not significantly different. Although valid for adults (Walne and Mann, 1975; Bodoy et al., 1986), OM/DW seems to be a poor indicator for $C$. gigas larvae, probably due to an erroneous estimation of organic matter. The method makes an overestimation of organic matter by integrating the organic weight of the shell. As Walne and Millican (1978) reported that the shell of $C$. gigas spat can contain 3 to $5.2 \%$ organic matter and, taking into account its weight, this organic fraction can represent 35 to $59 \%$ of the total organic matter of the animal. This index is probably better at conveying the relationship of flesh to shell than representing larval quality. The results of the present study, therefore, clearly demonstrate that the $\mathrm{OM} / \mathrm{DW}$ is not suitable for the evaluation of larval performances in $C$. gigas. The two 
other indices, however, rely on the evolution of lipids over time. OLI and TAG/ST are correctly correlated with zootechnical performances, confirming both the qualitative and quantitative importance of lipids in the early life stages of molluscs. Concerning the quality of lipids, bivalves are known to have high concentrations of PUFA and especially n-3 (Knauer and Southgate, 1999) and although, among these, the importance of DHA and EPA is generally recognised, the specific needs of larvae and juveniles of different species of mollusc is not yet clearly established (Volkman and Brown, 2006).

Our results also showed unequivocally that feeding with $C$. calcitrans forma pumilum (Cp) alone gave better larval development, competence and metamorphosis results than other single species diets. Results with this microalga alone were sometimes equivalent or better than a mixed diet, confirming previous findings with the same species (Millican and Helm, 1973; Nascimento, 1980). Additionally our results agree with those of Helm and Laing (1987) and Utting and Spencer (1991), which recommend the use of the bi-specific mixture TCp to obtain optimal performance in $C$. gigas larvae from the earliest age $\left(2^{\text {nd }}\right.$ day). Another interesting point is that the bi-specific TCp diet leads to the same larval development performances as the tri-specific PTCp diet, as already suggested by Rico-Villa et al. (1996). In contrast, the other monospecific diets, $P$. lutheri $(P)$ and $I$. aff. galbana $(T)$, as well as their combination (PT), did not allow the production of competent larvae after 18 days of rearing. At the beginning of rearing (day 8), it was noted that larvae fed on either of these microalgae had a very low overall lipid index (less than $5 \%$ ), which could be explained by a very low ingestion of these species.

The inadequacy of $P$. lutheri due to its lack of ingestion by $C$. gigas larvae and postlarvae has already been seen in other studies (Ponis et al., 2003; Ponis et al., 2006). Additionally, the two flagellates used in our study have the same lipid content and their quantitative contribution of long-chain PUFA is similar (Chu and Web, 1984; Langdon and Waldock, 1981; Delaunay et al., 1993). When these species are associated with C. calcitrans forma pumilum, the overall lipid index of the larvae is increased, but remains lower than that achieved with the diatom alone by the end of rearing. These results confirm that the larvae of C. gigas preferentially ingest this diatom compared with the two Prymnesiophyceae, despite the similar size of these microalgae (Rico Villa et al., 2006). In the more advanced stages of larval development, a higher overall lipid index seems to indicate that $I$. aff. galbana is better ingested than $P$. lutheri. Whether it is supplied alone or in a mixture, the nutritional contribution of $P$. lutheri to $C$. gigas larval growth and development is low. $P$. lutheri is, therefore, of limited interest for feeding this oyster species during its larval stages.

\section{Conclusion}

The experiments reported here showed that:

1. The best development of $C$. gigas larvae was recorded at the highest food level supplied. This performance was accompanied by the highest lipid deposition expressed through TAG/ST ratio as well as through OLI and, both lipids indices were well correlated with zootechnical performances.

2. When fed $P$. lutheri or $I$. aff. galbana, poor larval development and a low lipid deposition were reported, while C. calcitrans f. pumilum allowed good larval development and high lipid storage maintenance throughout larval life, whether it was supplied alone or in combination with other species. 
3. In contrast OM/DW does not appear to be suitable for the evaluation of larval performances in C. gigas.

\section{Acknowledgements}

This work could not have been completed without the technical support of the team at the Argenton Ifremer station - C. Mingant, I. Quéau, L. Lebrun and P. Le Souchu - and the help of a project student A. Henocq, all of whom we wish to thank. We are also grateful to the Tunisian ministry of higher education, scientific research and technology, the French embassy in Tunis and the Centre Régional des Euvres Universitaires et Scolaires de Rennes, who contributed to the funding of the doctoral visit of one of the authors to France. This work has been carried out throughout SETTLE project and was partially funded by FP7/2007-2013 under agreement $n^{\circ} 222043$.

\section{References}

Auby, I., Maurer, D., 2004. Etude de la reproduction de l'huître creuse dans le Bassin d'Arcachon- Rapport final. R.INT.DEL/AR 04.03, 201 p.+ Annexes.

AGRESTE, 2005. AGRESTE Primeur, premier recensement de la conchyliculture 2001. Agreste Cahiers $n^{\circ} 1$, février 2005, $89 \mathrm{pp}$.

Baker, S.M., Mann, R., 1994. Feeding ability during settlement and metamorphosis in the oyster Crassostrea virginica (Gmelin, 1791) and the effects of hypoxia on post-settlement ingestion rates. J. Exp. Mar. Biol. Ecol. 181, 223-253.

Bodoy, A., Prou, J., Berthomé, J.P., 1986. Etude comparative de différents indices de condition chez l'huître creuse (Crassostrea gigas). Haliotis 15, 173-182.

Brown, W.J., Sullivan, T.R., Greenspan, P., 1992. Nile Red staining of lysosomal phospholipid inclusions. Histochemistry 97(4), 349-354.

Buestel, D., Ropert, M., Prou, J., Goulletquer, P., 2009. History, status, and future of oyster culture in France. J Shellfish Res. 28(4), 813-820.

Castell, L.L., Mann, R., 1994. Optimal staining of lipids in bivalve larvae with Nile Red. Aquaculture 119(1), 89-100.

Chu, F.L.E., Webb, K.L., 1984. Polyunsaturated fatty acids and neutral lipids in developing larvae of the oyster Crassostrea virginica. Mar. Biol. 110, 229-236.

Coon, S.L., Fitt, W.K., Bonar, D.B., 1990. Competence and delay of metamorphosis in the Pacific oyster Crassostrea gigas. Mar. Biol. 106(3), 379-387.

Delaunay, F., Marty, Y., Moal, J., Samain, J.F., 1992. Growth and lipid class composition of Pecten maximus (L) larvae grown under hatchery conditions. J. Exp. Mar. Biol. Ecol. 163(2), 209-219.

Farias, A., Bell, J.G., Uriarte, I., Sargent, J.R., 2003. Polyunsaturated fatty acids in total lipid and phospholipids of Chilean scallop Argopecten purpuratus (L.) larvae : effects of diet and temperature. Aquaculture 228 (1-4), 289-305.

Fraser, A.J., 1989. Triacylglycerol content as condition index for fish, bivalve and crustacean larvae. J. Fish. Res. Board Can. 46, 1868-1873.

Gallager, S.M., Mann, R., 1981. Use of lipid-specific staining techniques for assaying condition culture bivalve larvae. J Shellfish Res. 1, 69-73.

Gallager, S.M., Mann, R., 1986. Individual variability in lipid content of bivalve larvae quantified histochemically by absorption photometry. J. Plankton Res. 8(5), 927-937.

Gallager, S.M., Mann, R., Sasaki, G.C., 1986. Lipid as an index of growth and viability in three species of bivalve larvae. Aquaculture 56(2), 81-103. 
Grizel, H., Héral M., 1991. Introduction into France of the Japanese oyster (Crassostrea gigas). J. Cons. Explor. Mer. 47, 399-403.

Greenspan, P., Fowler, S.D., 1985. Spectrofluorometric studies of the lipid probe, Nile red. J. Lipid Res. 26(7), 781-789.

Greenspan, P., Mayer, E.P., Fowler, S.D., 1985. Nile Red, a selective fluorescent stain for intracellular lipid droplets. J. Cell Biol. 100(3), 965-973.

Hakanson, J.L., 1989. Analysis of lipid components for determining the condition of anchovy larvae, Engraulis mordax. Mar. Biol. 102, 143-151.

Haws, M.C., DiMichelle, L., Hand S.C., 1993. Biochemical changes and mortality during metamorphosis of the Eastern oyster Crassostrea virginica and the Pacific oyster, Crassostrea gigas. Mol. Mar. Biol. Biotechnol. 2(4), 207-217.

Helm, M.M., Laing, I., 1987. Preliminary observations on the nutritional value of Tahiti Isochrysis to bivalve larvae. Aquaculture 62, 281-288.

Helm, M.M., Bourne, N., Lovatelli, A., 2004. Hatchery culture of bivalves. A practical manual. In: Lovatelli, A. (Ed.), FAO Fisheries Technical Paper 471. Food and Agriculture Organization of the United, Nations Publishing, Rome, Italy. 177 pp.

Jackson, D.L., 1993. Use of Nile Red as a histochemical technique for monitoring physiological condition of bivalve larvae. Bull. Aquacul. Assoc. Canada 93-4, 32-34.

Langdon, C.J., Waldock, M.J., 1981. The effect of algal and artificial diet on the growth and fatty acid composition of Crassostrea gigas spat. J. Mar. Biol. Ass. U.K. 62, 431-448.

Lucas, A., Rangel, C., 1983. Detection of the first larval feeding in Crassostrea gigas, using the epifluorescence microscope. Aquaculture 30(1-4), 369-374.

Millican, P.F., Helm, M.M., 1973. Preliminary observations on the culture of the larvae of Pacific oyster, Crassostrea gigas Thunberg. ICES, C.M. - 1973/K - 33, 10 pp.

Nascimento, I.A., 1980. Growth of the larvae of Crassostrea gigas Thunberg, fed with different algal species at high cell concentrations. J. Cons. Inter. Explor. Mer 39(2), 134-139.

Nevejan, N., Saez, I., Gajardo, G., Sorgeloos P., 2003. Energy vs. essential fatty acids: what do scallop larvae (Argopecten purpuratus) need most? Comp. Biochem. Physiol. Part B 134(4), 599-613.

Nicolas, L., 1999. Etude sur la métamorphose et le développement postlarvaire de la coquille St Jacques, Pecten maximus en écloserie. Eléments de comparaison avec l'huître creuse Crassostrea gigas. Thèse de Doctorat, Université de Brest, 224 pp.

Normand, J., Ernande, B., Haure, J., McCombie, H., Boudry P., 2009. Reproductive effort and growth in Crassostrea gigas: comparison of intensively reared 5-month-old diploid and triploid oysters issued from natural crosses or chemical induction. Aquat. Biol., 7 (3), 229241.

Pernet, F., Tremblay, R., Bouget E., 2003. Biochemical indicator of sea scallop (Placopecten magellanicus) quality based on lipid class composition. Part I: Broodstock conditioning and young larval performance. J Shellfish Res. 22 (2) : 365-375.

Pernet, F., Tremblay, R., Langdon, C., Bourget, E., 2004. Effect of additions of dietary triacylglycerol microspheres on growth, survival, and settlement of mussel (Mytilus sp.) larvae. Mar. Biol. 144(4), 693-703.

Pernet, F., Bricelj, V.M., Cartier, S., 2006. Lipid class dynamics during larval ontogeny of sea scallops, Placopecten magellanicus, in relation to metamorphic success and response to antibiotics. J. Exp. Mar. Biol. Ecol. 329(2), 265-280.

Ponis, E., Robert, R., Parisi, G., 2003. Nutritional value of fresh and concentrated algal diets for larval and juvenile Pacific oysters (Crassostrea gigas). Aquaculture 221(1-4), 491-505.

Ponis, E., Probert, I., Véron, B., Le Coz, J.R., Mathieu, M., Robert, R., 2006. Nutritional value of six pavlovophyceae for Crassostrea gigas and Pecten maximus larvae. Aquaculture 254, 544-553.

Pontual de, H., Robert, R., Miner, P., 1998. Study of bivalve larval growth using image processing. Aquac. Eng. 17, 85-94.

Pouvreau, S., Maurer, D., Auby, I., Soletchnik, P., Mille, D., Bernard, I., Bédier, E., 2008. Temporal variability in the Pacific oyster spatfall along the French coast: a new monitoring project. PHYSIOMAR 08 1-4 September 2008, Brest, France, Book of Abstract, 147-147. 
Powell, E.N., Bochenek, E.A., Klinck, J.M., Hofmann, E.E., 2002. Influence of food quality and quantity on the growth and development of Crassostrea gigas larvae: a modelling approach. Aquaculture 210(1-4), 89-117.

Rico-Villa, B., Le Coz, J.R., Mingant, C., Robert, R., 2006. Influence of phytoplankton diet mixtures on microalgae consumption, larval development and settlement of the Pacific oyster Crassostrea gigas (Thunberg). Aquaculture 256(1-4), 377-388.

Rico Villa B., Pouvreau S., Robert R., 2009. Influence of food density and temperature on ingestion, growth and settlement of Pacific oyster larvae Crassostrea gigas. Aquaculture, 287: 395-401.

Robert, R., Gérard, A., 1999. Bivalve hatchery techniques: current situation for the oyster Crassostrea gigas and the scallop Pecten maximus. Aquat. Living Resour. 12(2), 121-130.

Robert, R., Chrétiennot-Dinet, M.J., Kaas, R., Martin-Jézéquel, V., Moal, J., Le Coz, J.R., Nicolas, J.L., Bernard, E., Connan, J.P., Le Dean, L., Gourrierec, G., Leroy, B., Quéré, C., 2004. Amélioration des productions phytoplanctoniques en écloserie de mollusques: caractérisation des microalgues fourrage, RI DRV/RA-2004-05, 149 pp.

Róg, T., Pasenkiewicz-Gierula, M., Vattulainen, I., Karttunen M., 2009. Ordering effects of cholesterol and its analogues. Biochim. Biophys. Acta 1788, 97-121.

Tremblay R., Cartier, S., Miner, P., Pernet F., Quéré, C., Moal, J., Muzellec, M.L., Mazuret, M., Samain, J.F., 2007. Effect of Rhodomonas salina addition to a standard hatchery diet during the early ontogeny of the scallop Pecten maximus. Aquaculture 262 (2007) 410-418 Utting, S.D., Spencer, B.E., 1991. The hatchery culture of bivalve mollusc larvae and juveniles. Laboratory Leaflet MAFF Fisheries Research of Lowestoft, No. 68, 31 pp.

Walne, P.R., Mann, R., 1975. Growth and biochemical composition in Ostrea edulis and Crassostrea gigas. In Proceedings of the ninth European Marine Biology Symposium, $\mathrm{H}$. Barnes (Ed), pp 587-607, Aberdeen University Press, Aberdeen Scotland.

Walne, P.R., 1966. Large scale culture of larvae of Ostrea edulis L. Fish. Invest., II 25, 1-52. 


\section{Figures}
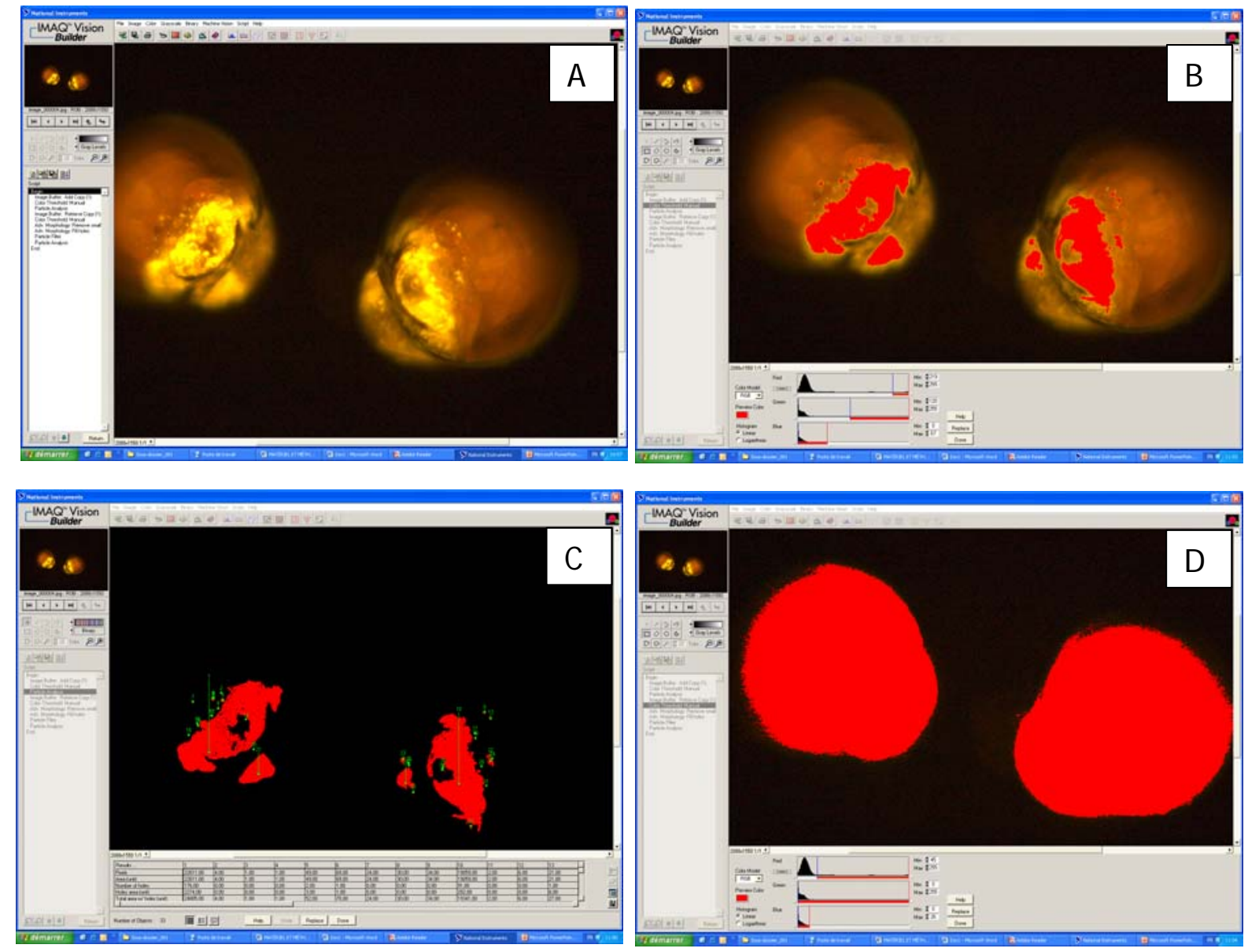

Fig. 1. The different steps in image analysis with the program 1MAQ vision builder (National Instrument).

A: open file containing the photographs taken with the Leica colour camera,

B: adjustment of the grey-scale corresponding to the lipid surface revealed by Nile Red,

C: automatic calculation of lipid areas selected as pixels,

D: adjustment of the grey-scale corresponding to the total surface of the larva and determination of the area as pixels. 


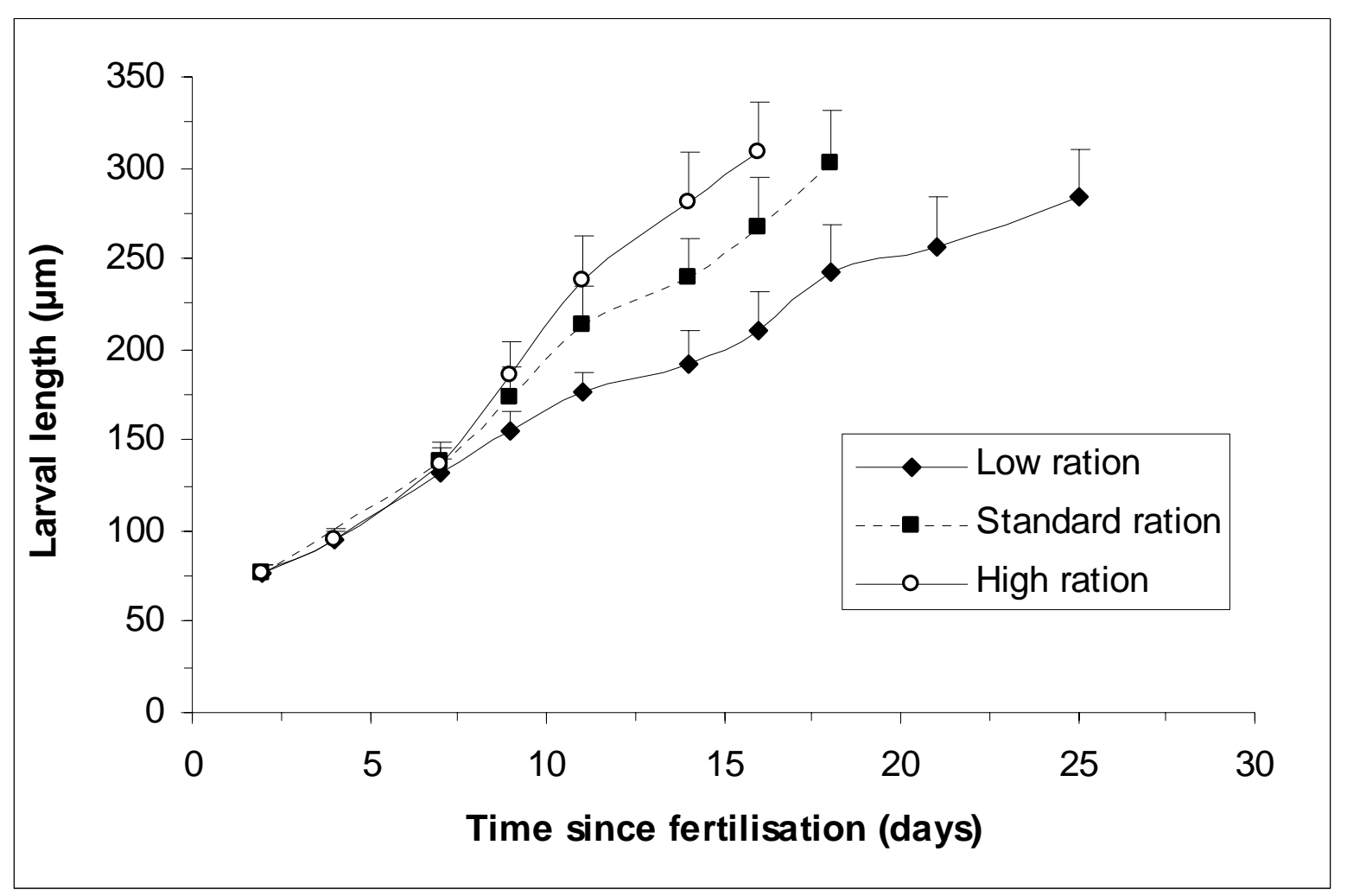

Fig. 2. Larval growth of $C$. gigas fed at three rations. Vertical bars represent standard deviations $(n=3)$.

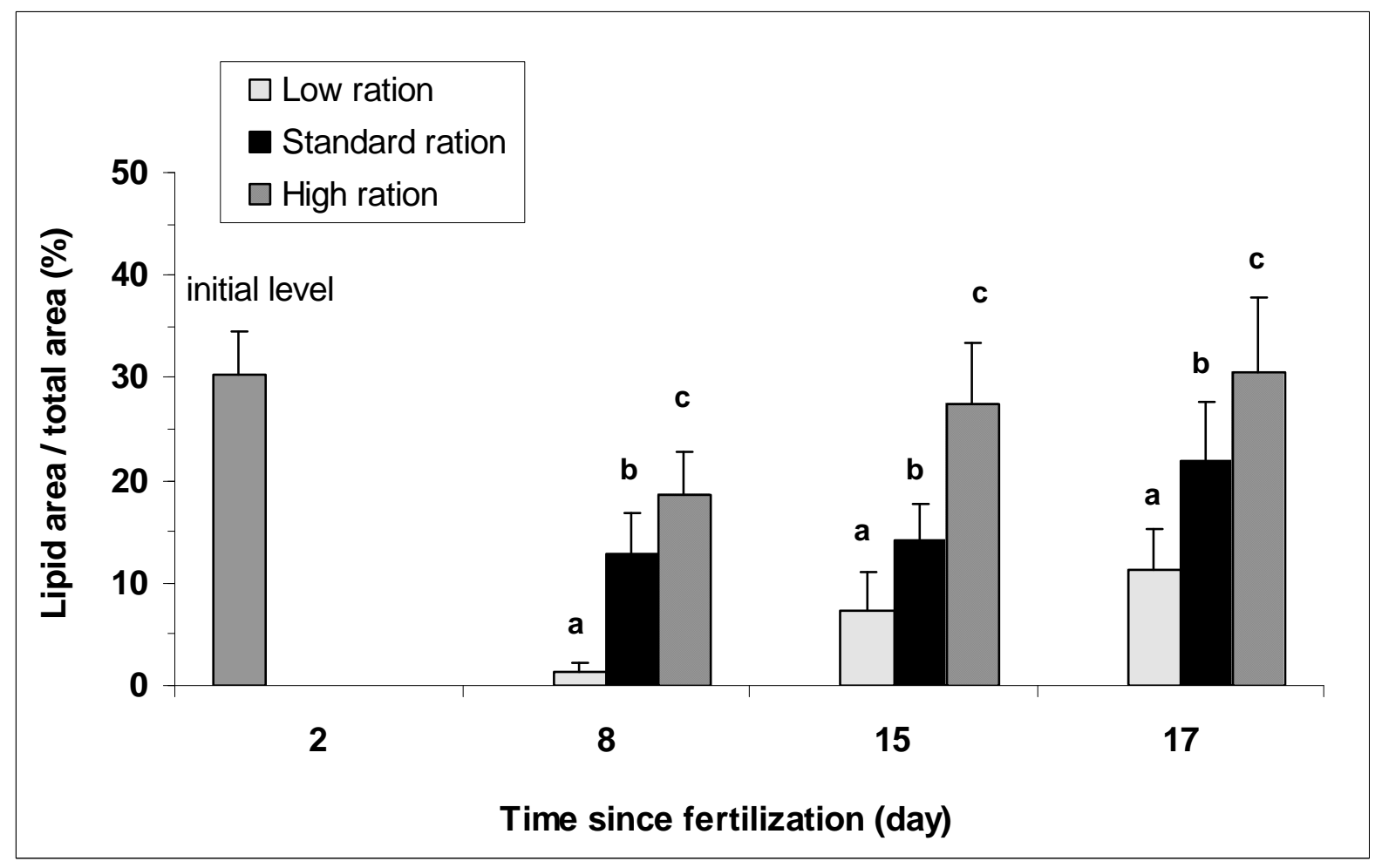

Fig. 3. Development of lipid reserves in $C$. gigas larvae fed at three rations. Vertical bars represent standard deviations $(n=3)$. For each date, the values with the same letter are not significantly different at the $5 \%$ level. 


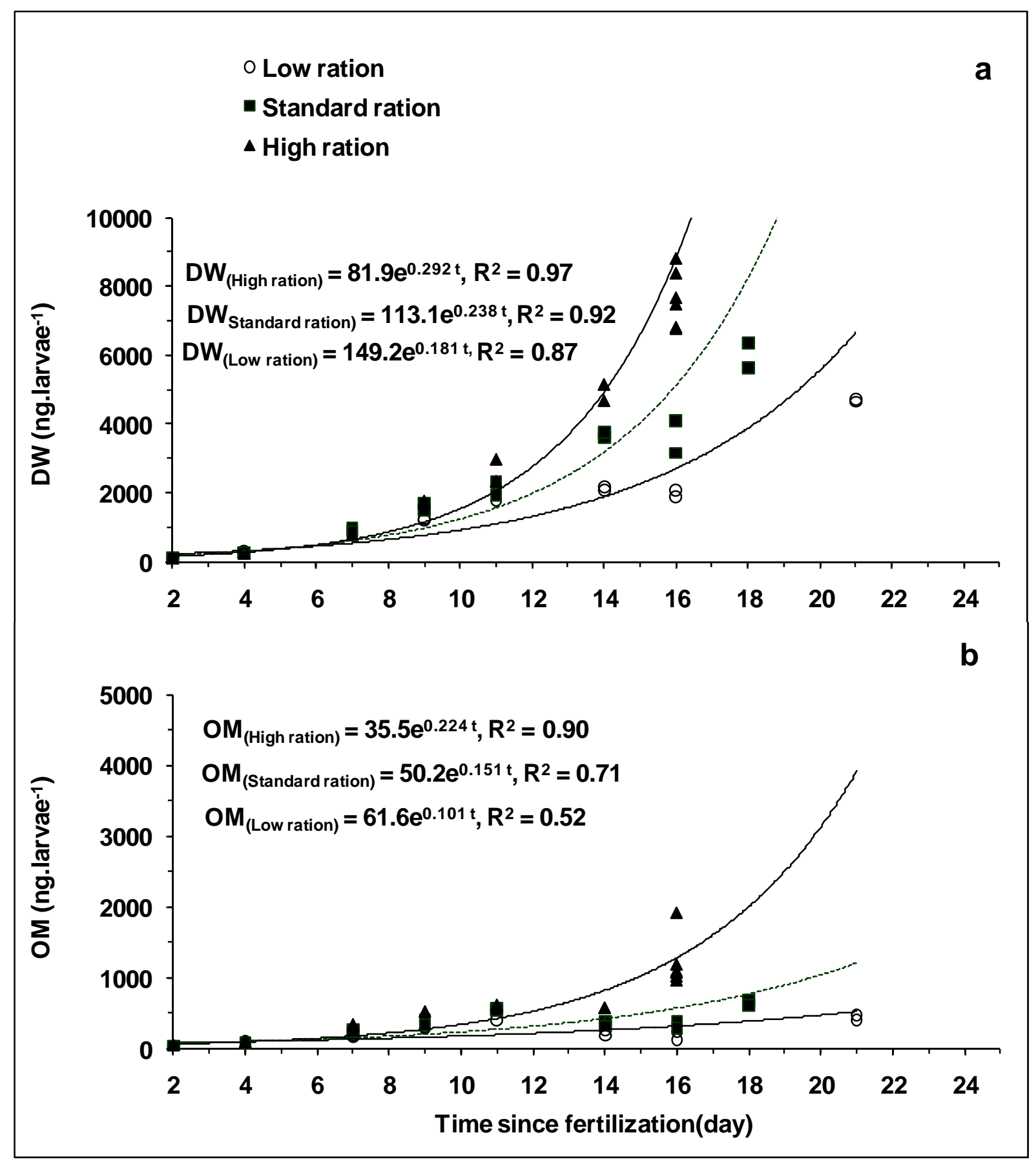

Fig. 4. Evolution of dry weight (DW) and organic matter (OM) over the course of larval development in $C$. gigas fed at three rations $(n=2)$. 


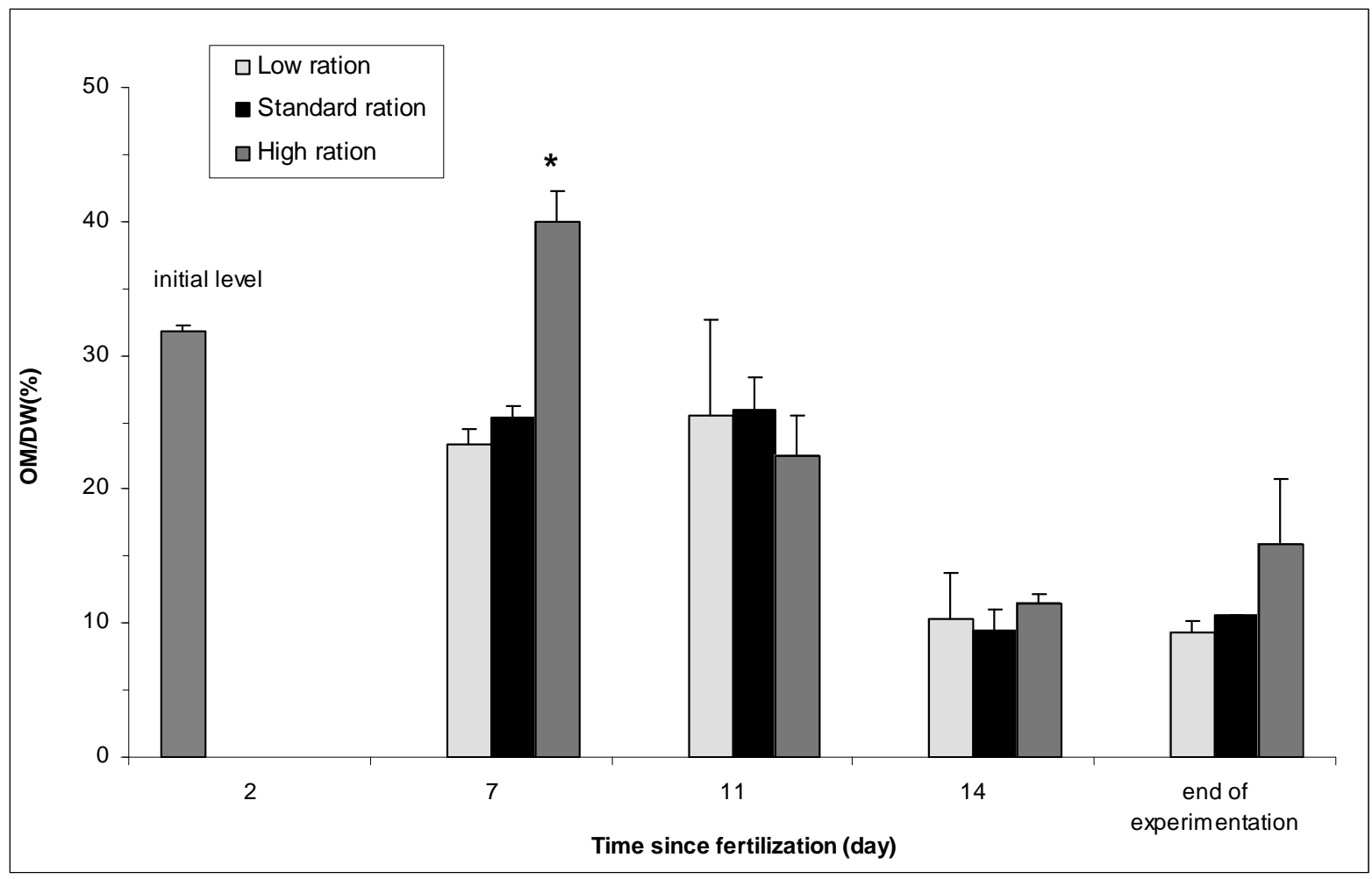

Fig. 5. Evolution of the OM/DW ratio (\%) in C. gigas larvae fed at three different rations. Vertical bars represent standard deviations $(n=2)$. * indicates a significant difference at the 5 $\%$ level. 


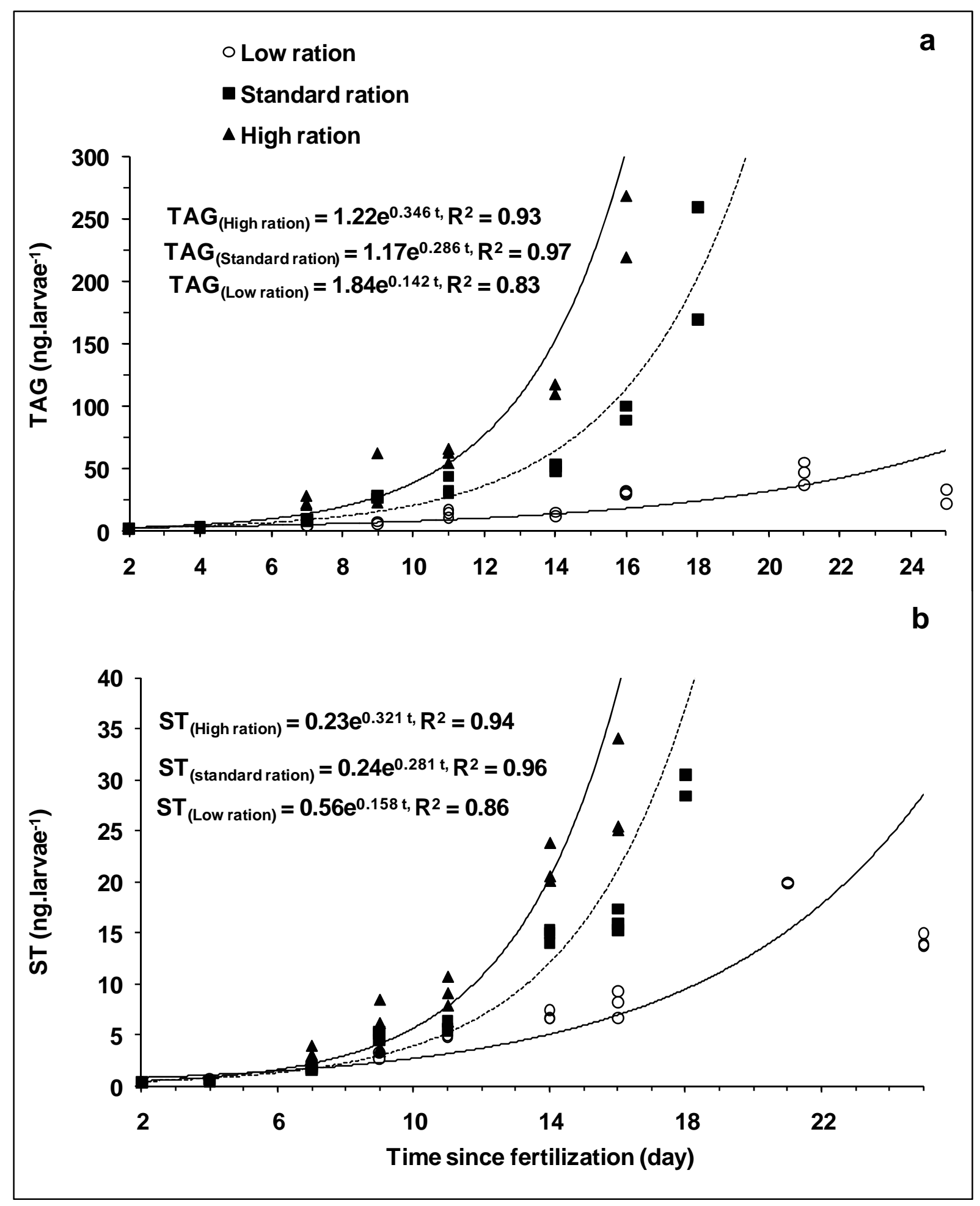

Fig. 6. Evolution of triacylglycerols TAG (a) and sterols ST (b) in C. gigas larvae fed at three rations $(n=2)$. 


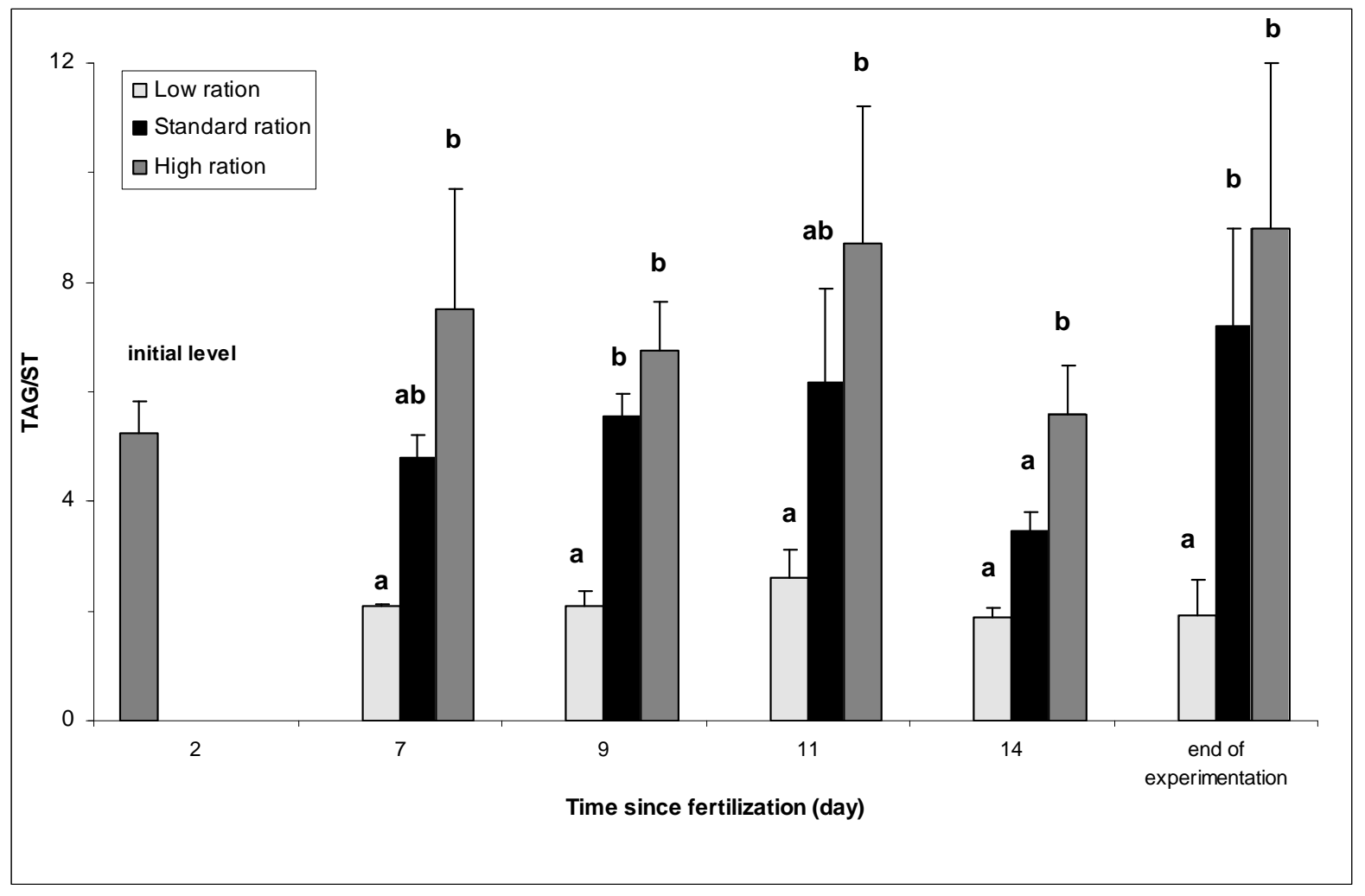

Fig. 7. Evolution of the structural biochemical index TAG/ST in C. gigas larvae fed at three rations. Vertical bars represent standard deviations $(n=2)$. For each date, the values with the same letter are not significantly different at the $5 \%$ level.

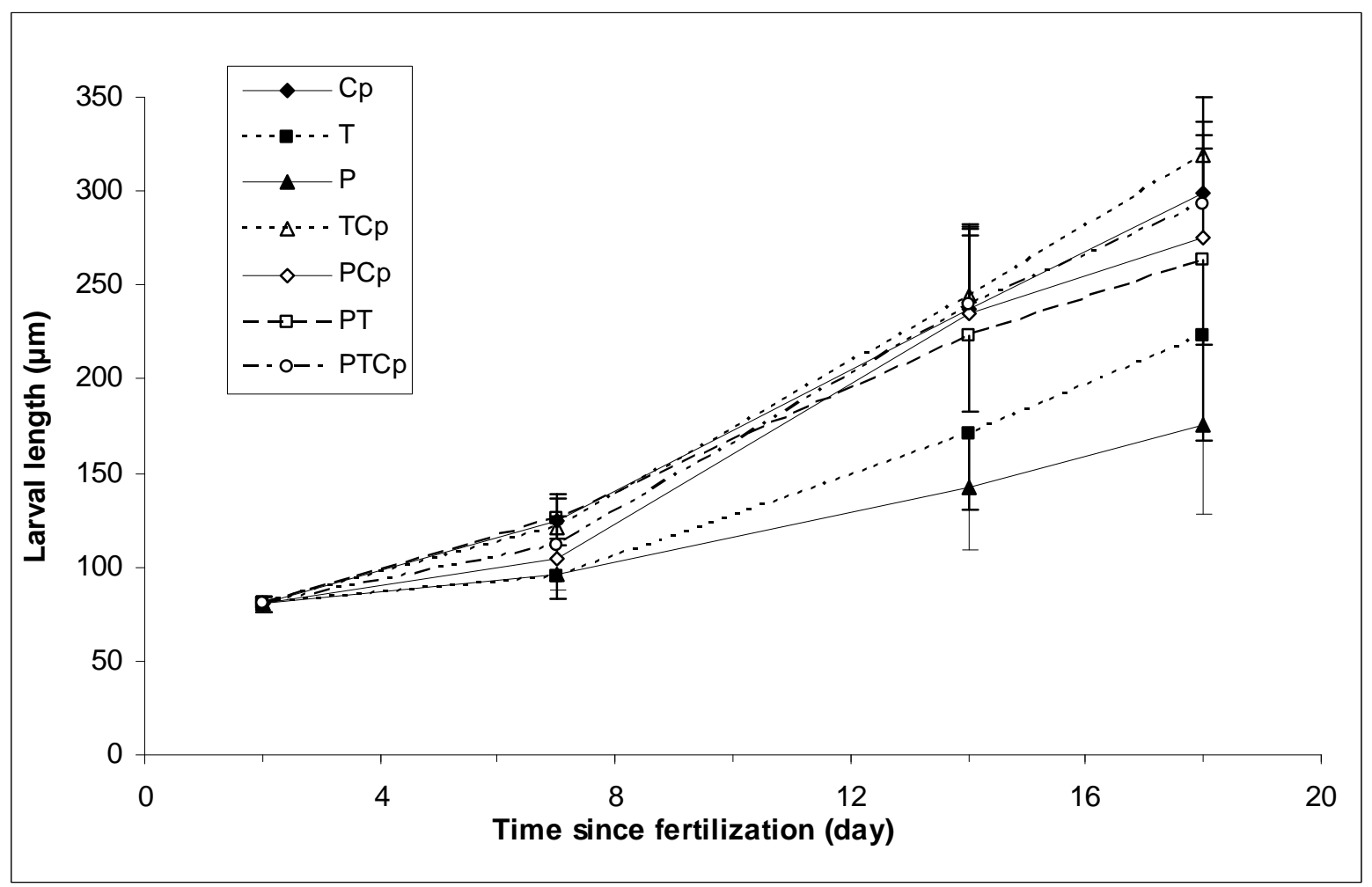


Fig. 8. Growth of $C$. gigas larvae fed on different species of microalgae or species mixtures. Vertical bars represent standard deviations $(n=3)$.

P: Pavlova lutheri: CCAP 931/1, T: Isochrysis affinis galbana, Cp: Chaetoceros calcitrans forma pumilum; PT, PCp and TCp: bi-specific mixtures mixed in equal proportions, with equal volume; PTCp: tri-specific mixture.

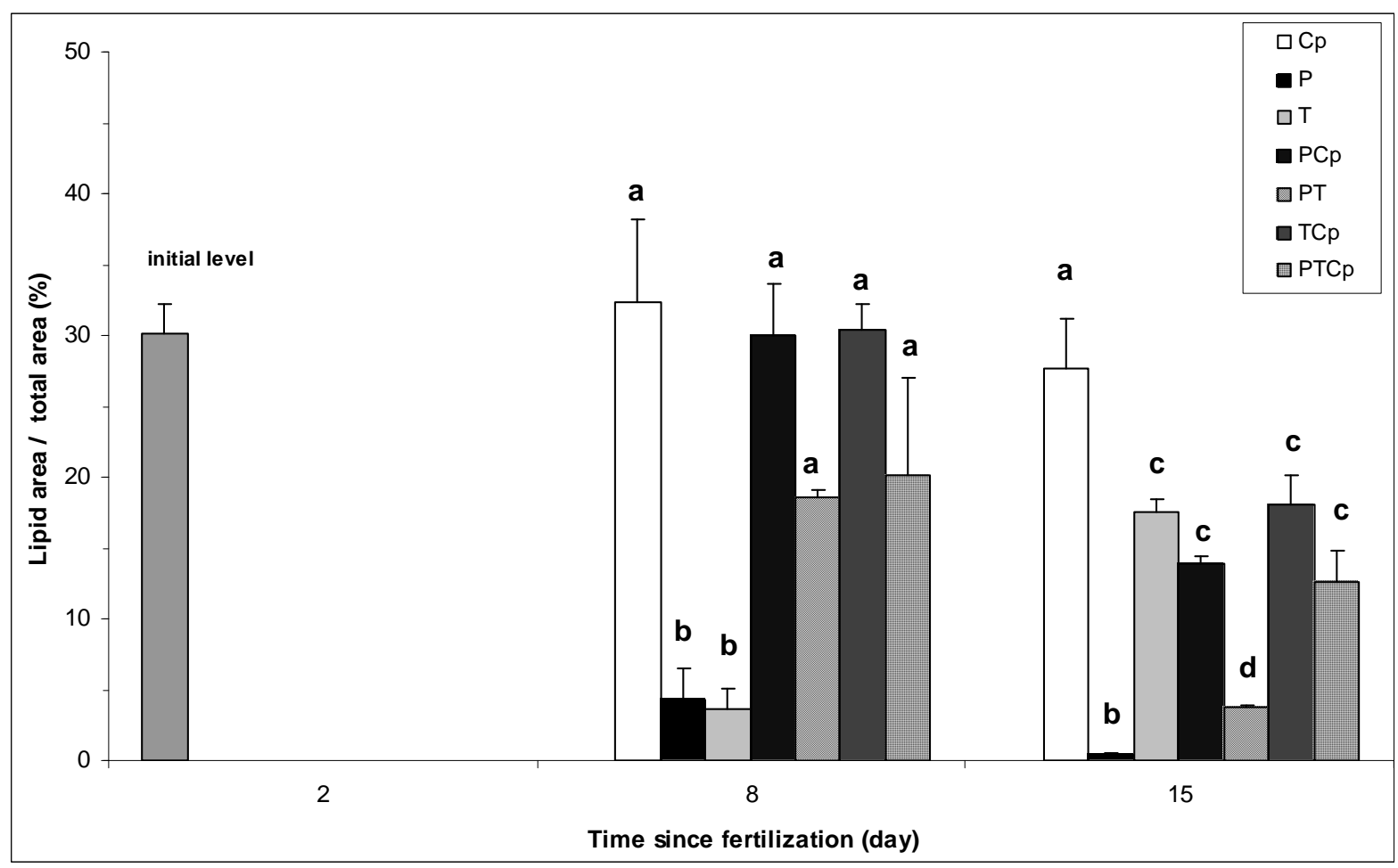

Fig. 9. Development of lipid reserves in C. gigas larvae fed on different species of microalgae or species mixtures. Vertical bars represent standard deviations $(n=3)$.

For each date, the values with the same letter are not significantly different at the $5 \%$ level.

P: P. lutheri: CCAP 931/1, T: I. affinis galbana, Cp: C. calcitrans forma pumilum; PT, PCp and TCp: bi-specific mixtures mixed in equal proportions, with equal volume; PTCp: trispecific mixture. 


\section{Tables}

\section{Table 1.}

Performances (mean \pm standard deviation) in larval rearing of $C$. gigas fed at three increasing food rations. The values with the same letter in the same column are not significantly different at the $5 \%$ level.

\begin{tabular}{|c|c|c|c|c|c|}
\hline $\begin{array}{l}\text { Ration } \\
\text { (cells } \mu l^{-1} \mathrm{~d}^{-1} \text { ) }\end{array}$ & $\begin{array}{l}\text { Duration of } \\
\text { rearing }(d)\end{array}$ & $\begin{array}{l}\text { Survival to } \\
\text { the end of } \\
\text { rearing (\%) }\end{array}$ & $\begin{array}{l}\text { Growth rate }(\mu \mathrm{m} \\
\left.\qquad \mathrm{d}^{-1}\right)\end{array}$ & $\begin{array}{c}\text { Competence } \\
(\%)\end{array}$ & $\begin{array}{c}\text { Metamorphosis } \\
(\%)\end{array}$ \\
\hline $\begin{array}{l}\text { Half ration } \\
(25-100)\end{array}$ & 25 & $86(5)^{a}$ & $9.0(1.2)^{a}$ & $31.8(1.3)^{\mathrm{a}}$ & $49.7(5.9)^{\mathrm{a}}$ \\
\hline $\begin{array}{l}\text { Standard } \\
\text { ration } \\
200)\end{array}$ & 18 & $96(2)^{b}$ & $14.1(1.9)^{b}$ & $43.6(4.6)^{b}$ & $83.5(2.3)^{b}$ \\
\hline $\begin{array}{l}\text { Double ration } \\
(100-400)\end{array}$ & 16 & $94(2)^{\mathrm{ab}}$ & $16.5(1.9)^{\mathrm{c}}$ & $86.2(3.2)^{\mathrm{c}}$ & $79.7(9.9)^{b}$ \\
\hline
\end{tabular}




\section{Table 2.}

Larval rearing performances (mean \pm standard error) of $C$. gigas fed on different species of microalgae and mixtures. P: P. lutheri: CCAP 931/1, T: I. affinis galbana, Cp: C. calcitrans forma pumilum; PT, PCp and TCp: bi-specific mixtures mixed in equal proportions, with equal volume; PTCp: tri-specific mixture.

\begin{tabular}{cccccc}
\hline Diet & $\begin{array}{c}\text { Duration of } \\
\text { rearing (d) }\end{array}$ & $\begin{array}{c}\text { Survival to the } \\
\text { end of rearing }(\%)\end{array}$ & $\begin{array}{c}\text { Growth rate } \\
\left(\mu \mathrm{m} \mathrm{d}^{-1}\right)\end{array}$ & $\begin{array}{c}\text { Competence } \\
(\%)\end{array}$ & $\begin{array}{c}\text { Metamorphosis } \\
(\%)\end{array}$ \\
\hline Cp & 18 & $74.7(8.5)^{\mathrm{a}}$ & $13.6(1.9)^{\mathrm{a}}$ & $79.6(5.3)^{\mathrm{a}}$ & $82.0(0.7)^{\mathrm{a}}$ \\
T & 18 & $70.0(11.7)^{\mathrm{a}}$ & $8.9(3.5)^{\mathrm{bc}}$ & $* \star *$ & $* \star *$ \\
P & 18 & $80.2(9.9)^{\mathrm{ac}}$ & $5.9(2.9)^{\mathrm{cd}}$ & $* \star *$ & $* * *$ \\
TCp & 18 & $90.5(0.9)^{\mathrm{b}}$ & $15.0(1.9)^{\mathrm{ae}}$ & $85.7(7.2)^{\mathrm{a}}$ & $79.4(4.9)^{\mathrm{a}}$ \\
PCp & 18 & $90.8(2.8)^{\mathrm{b}}$ & $12.2(2.9)^{\mathrm{abe}}$ & $28.3(8.4)^{\mathrm{b}}$ & $56.7(6.9)^{\mathrm{b}}$ \\
PT & 18 & $87.3(0.3)^{\mathrm{bc}}$ & $11.5(2.8)^{\mathrm{abe}}$ & $* * *$ & $* * *$ \\
PTCp & 18 & $90.7(5.2)^{\mathrm{b}}$ & $13.3(2.7)^{\mathrm{ae}}$ & $77.5(5.6)^{\mathrm{a}}$ & $83.3(5.3)^{\mathrm{a}}$ \\
\hline
\end{tabular}

